\title{
„DWIE DUSZE” - CZYLI EWOLUCJA TOŻSAMOŚCI SPOŁECZNEJ I NARODOWEJ LUDNOŚCI CHŁOPSKIEJ GALICJI W DRUGIEJ POŁOWIE XIX I NA POCZĄTKU $X X$ WIEKU
}

\author{
Paweł Jakubiec \\ Uniwersytet Pedagogiczny im. KEN w Krakowie
}

\author{
ABSTRACT \\ "TWO SOULS" - THE EVOLUTION OF SOCIAL AND NATIONAL \\ IDENTITY OF PEASANTS IN GALICIA IN THE LATE $19^{\text {TH }}$ AND EARLY \\ $20^{\text {TH }}$ CENTURY
}

The aim of this paper is to characterize the evolution of social and national identity of Galician peasants in the late 19th and early 20th century. The author shows a few examples from the sources and studies on the subject, from which we can find out how these areas of peasant consciousness evolved. It was possible for changes to take place after several social and economic reforms were adopted. These changes contributed to the development of active civic attitudes and a greater participation in political life. At the same time, the emergence of peasant parties and the activities carried out by politicians contributed to the evolution of national identity. The awakening of national awareness was greatly influenced by the press and publications. A major role was also played by schools, the Church and the participation in social life of rural communities. The social and national identity of peasants showed in the celebration of national holidays, political programs and the growth of press subscription among rural inhabitants of Galicia.

Key words: peasants, Galicia, national identity, social identity.

Słowa kluczowe: chłopi, Galicja, tożsamość narodowa, tożsamość społeczna.

Tematem niniejszego artykułu jest próba scharakteryzowania tożsamości chłopów w Galicji w drugiej połowie XIX i na początku XX wieku. Zakres chronologiczny pracy obejmuje okres po 1848 roku. Za datę końcową przyjąłem rok 1918, czyli odrodzenie się niepodległej Polski. Należy jednak pamiętać, że tożsamość chłopska 
w kolejnych latach podlegała dalszej ewolucji. Ziemie Galicji Zachodniej stanowią ramy geograficzne artykułu. Informacje zaczerpnięte ze źródeł pozwalają na szczegółowe przyjrzenie się kilku powiatom oraz ośrodkom miejskim takim jak Kraków czy Tarnów, a także - wychodząc już poza Galicję Zachodnią - Lwów. Na podstawie zachodzących tam procesów i wydarzeń możemy ukazać rozwój tożsamości społecznej i świadomości narodowej ludności chłopskiej. Pisząc ten artykuł, w dużej mierze opierałem się na przykładach z pamiętników i wspomnień działaczy wiejskich omawianego okresu, w tym przedstawicieli społeczności lokalnych: wójtów i pisarzy gminnych, polityków pochodzenia chłopskiego oraz innych działaczy społecznych ${ }^{1}$. Najdokładniejszym obrazem wsi galicyjskiej z przełomu XIX i XX wieku są wspomnienia Wincentego Witosa, który doskonale analizuje wszelkie przejawy życia społeczności wiejskiej, w tym jej społecznego i narodowego rozwoju².

Wykorzystałem także źródła prasowe i publicystykę. W tytule pracy nawiązałem do broszury Jakuba Bojki Dwie dusze. Autor charakteryzował w niej chłopa oraz jego zachowania, postawy, mentalność i świadomość społeczną ${ }^{3}$ Została ona wydana w 1904 roku, kiedy apogeum osiągnął konflikt pomiędzy działaczami ludowymi a biskupem tarnowskim Leonem Wałęgą, który ogłosił zakaz czytania politycznej prasy chłopskiej. Za nieprzestrzeganie rozporządzenia groził brak rozgrzeszenia, a nawet ekskomunika. Mimo kościelnych kar i zakazów nie udało się powstrzymać wpływu publicystyki kształtującej świadomość społeczną i narodową.

Analizie poddałem także programy nowych partii politycznych reprezentujących chłopów. To, w jaki sposób ukazywano w nich kwestie społeczne oraz narodowe, również podlegało ewolucji na przełomie XIX i XX wieku. W niniejszym artykule wykorzystałem także wcześniejsze badania, dotyczące recepcji pewnych idei, mających wpływ na kształtowanie się tożsamości chłopskiej w omawianym okresie, oraz przejawów świadomości narodowej ludności wiejskiej, manifestujących się w obchodach świąt narodowych i podczas innych patriotycznych uroczystości ${ }^{4}$. Liczne opracowania i monografie posłużyły do ukazania historycznych wydarzeń i procesów, będących tłem rozwoju tożsamości chłopskiej w omawianym okresie ${ }^{5}$.

1 J. Bojko, Ze wspomnień, Warszawa 1959; F. Magryś, Żywot chłopa działacza, Handzlówka 2004; J. Sło mka, Pamiętniki włościanina od czasów pańszczyzny do czasów dzisiejszych, Kraków 1929.

2 W. Witos, Moje wspomnienia, cz. 1, Warszawa 1998.

3 J. Bojko, Dwie dusze, Warszawa 1949.

4 F. Ziejka, Złota legenda chtopów polskich, Warszawa 1984; Insurekcja kościuszkowska w dziejach i tradycji, red. J. Gmitruk, A. Stawarz, Warszawa 2004; J. Gmitruk, J. Mazurek, Tradycja kościuszkowska w ruchu ludowym, Warszawa 2004.

5 H. Brodowska, Chłopi o sobie i Polsce. Rozwój świadomości narodowej, Warszawa 1984; J. Ha mpe1, Chtopów polskich drogi do demokracji. Studia i szkice, Kraków 2008; Historia chtopów polskich, t. 2: Okres zaborów, red. S. Inglot, Warszawa 1972; J. Molenda, Chtopi, naród, niepodległość. Ksztattowanie się postaw narodowych i obywatelskich chlopów w Galicji i Królestwie Polskim w przededniu odrodzenia Polski, Warszawa 1999; J.Z. Pająk, Od autonomii do niepodlegtości. Kształtowanie się postaw politycznych i narodowych spoteczeństwa Galicji w warunkach Wielkiej Wojny 1914-1918, Kielce 2012; K. Stauter-Halsted, The Nation in the Village. The Genesis of Peasant National Identity in Austrian Poland 1848-1914, London-New York 2001. 


\section{EWOLUCJA TOŻSAMOŚCI SPOŁECZNEJ CHŁOPÓW PO 1848 ROKU}

Momentem przełomowym w historii włościan w zaborze austriackim była Wiosna Ludów, kiedy to ogłoszono reformę uwłaszczeniową i zniesiono poddaństwo osobiste. Zaczął się wtedy kolejny rozdział w historii chłopów galicyjskich. Stali się oni posiadaczami ziemi, mogli zmieniać miejsce swojego zamieszkania oraz w większym stopniu uczestniczyć w życiu społecznym i politycznym własnej wspólnoty oraz kraju.

Zniesienie pańszczyzny oraz zmiana stosunków społeczno-gospodarczych na wsi przyczyniły się do rozwoju świadomości społecznej i obywatelskiej ludności chłopskiej. Coraz częściej jej przedstawiciele identyfikowali się ze swoją grupą, warstwą społeczną, a także dążyli do walki o prawa i przywileje dla ludności włościańskiej. Chcieli w większym stopniu uczestniczyć w życiu społecznym i politycznym własnych miejscowości, gmin, powiatów. Ewolucja stosunków oraz zmiany były jednak procesem długotrwałym, wymagającym także pewnych zmian prawodawstwa austriackiego. Ogromną rolę w życiu gmin i powiatów odegrali wójtowie i pisarze gminni, mający kontakt z szerszym światem, niejednokrotnie jako jedyni umiejący czytać i pisać. Oddziaływali na ludność poprzez szerzenie oświaty, kultury i pobudzanie życia ekonomicznego wsi. Do najważniejszych działaczy pierwszego pokolenia chłopów popańszczyźnianych należeli Jan Słomka, Maciej Szarek czy Franciszek Magryś. W późniejszym okresie dołączyli do nich Jakub Bojko, Wincenty Witos i Jan Stapińskí.

Jednym z elementów tożsamości społecznej chłopów było wytworzenie się reprezentacji politycznej tej warstwy. Reformy administracji centralnej w Austrii umożliwiły im uczestnictwo w organach władzy, początkowo na skalę krajową we Lwowie, a następnie także na szczeblu centralnym w Wiedniu. Pierwszym chłopskim posłem był Jan Siwiec z Żywiecczyzny, który wszedł do Sejmu Krajowego w roku $1861^{7}$. Wraz z nim wybrano jeszcze kilkunastu posłów pochodzenia włościańskiego. Początkowo jednak sytuacja w Galicji nie była zbyt obiecująca. Jak wskazują sami pamiętnikarze chłopscy, zainteresowanie walką polityczną wśród ludności włościańskiej było niewielkie:

Co do życia politycznego, to przez długi czas po nastaniu konstytucji nie było znaku takiego życia. Wszelkie wybory: do sejmu czy parlamentu bardzo mało chłopów interesowały, mało kto o tem mówił i chciał coś wiedzieć. A gdy kto czasem o tem coś wspomniał, to drudzy zaraz odpowiadali: „Co mnie to obchodzi, kto posłem ostanie, - niech ta obiorą, kogo chcą; tam chłop niezdatny, bo nie ma nauki, a pan będzie trzymał z panami i dla chłopów nic tam nie zrobi, więc najlepiej nie zaprzątać sobie tem głowy, bo to nic dobrego"s.

Stopniowo jednak ulegało to zmianie i coraz częściej dopominano się o godną reprezentację polityczną warstwy chłopskiej. Rola posłów włościańskich była stale

${ }^{6}$ Historia chłopów polskich..., s. 234-240; K. Stauter-Halsted, op. cit., s. 84-86.

7 Ibidem, s. 68-72.

8 J. Słomka, op. cit., s. 167-168. 
umniejszana, ponieważ upominali się oni o swe prawa, tocząc spory z wyższymi warstwami, mającymi ugruntowaną i znacznie silniejszą pozycję w sejmie. Ziemianie i szlachta nie dostrzegali korzyści wynikających z rozwoju politycznego chłopów. Kolejny raz, jako zorganizowana grupa, włościanie zaistnieli w 1889 roku. Wtedy to do sejmu weszło czterech posłów, zakładając Klub Katolicko-Ludowy ${ }^{9}$. Od tego momentu rozpoczął się trwały udział przedstawicieli społeczności wiejskiej w Sejmie Krajowym. Kolejne reformy umożliwiły także chłopom zasiadanie w Radzie Państwa. Pierwszym przedstawicielem ludności włościańskiej w Wiedniu był Jan Potoczek z nowosądeckiego. Największa grupa posłów zasiadających w ławach sejmowych związana była z tworzącymi się partiami chłopskimi, takimi jak: Związek Stronnictwa Chłopskiego (1893), Stronnictwo Ludowe (1895), Polskie Stronnictwo Ludowe (1903), Stronnictwo Chrześcijańsko-Ludowe (1896) czy - w późniejszym okresie - PSL „Piast” (1913) i PSL „Lewica” (1913/1914). Należeli do nich: bracia Jan i Stanisław Potoczkowie, Jakub Bojko, Jan Stapiński, Wincenty Witos, Franciszek Krempa, Andrzej Średniawski i inni. Po reformie wyborczej z 1907 roku, poprzedzonej wielką kampanią polityczną na rzecz zmiany ordynacji, do Rady Państwa weszło 17 posłów, a w 1911 - 24. Przed wybuchem I wojny światowej w Sejmie Krajowym zasiadało 15 przedstawicieli reprezentujących interesy chłopskie. Rozwój świadomości społecznej prowadził do uczestnictwa chłopów w życiu politycznym na bardzo szeroką skalę ${ }^{10}$.

Dużą rolę w rozbudzaniu postaw obywatelskich odegrała prasa dla ludności włościańskiej. Najważniejszymi tytułami były: „Wieniec-Pszczółka”, „Przyjaciel Ludu”, „Piast”, „Przegląd Społeczny”, „Dzwon” oraz „Przodownica”. Z czasopism, które docierały na wieś, czerpano informacje o aktualnych wydarzeniach politycznych i nowinkach gospodarskich. Poruszano w nich także wiele kwestii problemowych, dotyczących życia wsi i jej mieszkańców. Publicyści starali się także za wszelką cenę promować wartość chłopów jako warstwy społecznej, pokazywać jej znaczenie oraz zwalczać pokutujące wśród jej przedstawicieli postawy poddańcze. Propagowano abstynencję oraz walkę z pijaństwem, starano się także wpoić chłopom, że nie muszą oni wykonywać pewnych gestów, czynności wobec szlachcica czy księdza ${ }^{11}$. Jak stwierdził J. Bojko, w mentalności chłopa istniały dwie dusze. Jedna z nich ciągle należała do sługi, bo tak było przez ponad 400 lat istnienia pańszczyzny. Druga okazała się buntownicza i skłaniała go do walki o należne mu prawa i godność. Tylko dzięki niej mógł on znaleźć swoje miejsce w społeczeństwie i narodzie ${ }^{12}$. Taki wydźwięk miały artykuły ogłaszane na łamach prasy dla ludu. Bywały one często powodem konfliktów między publicystami i wydawcami a władzami świeckimi i duchownymi. Bardzo często dochodziło do policyjnych konfiskat oraz zakazów czytania,

9 Historia chłopów polskich..., s. 474-478; S. Grodziski, Sejm Krajowy Galicyjski 1861-1914, Warszawa 1993, s. 183-191; Programy stronnictw ludowych. Zbiór dokumentów, red. S. Lato, W. Stankiewicz, Warszawa 1969, s. 579.

10 Ibidem, s. 579-590; K. Stauter-Halsted, op. cit., s. 216-242; Historia chtopów polskich..., s. 474-485; S. Grodziski, op. cit., s. 183-224.

11 J.R. Szaflik, O rząd chtopskich dusz, Warszawa 1976, s.10-20.

12 J. Bojko, Dwie dusze, s. 16-18. 
ogłaszanych przez księży z ambon kościelnych. Przynosiło to jednak bardzo często odwrotny skutek. Ogromna popularność, jaką cieszyły się artykuły Stojałowskiego, Wysłouchów, Bojki, Średniawskiego, Wincentego Witosa czy później Jana Dąbskiego i Józefa Rączkowskiego, przyczyniła się do rozwoju prasy ludowej. W 1901 roku było około 1380 prenumeratorów „Przyjaciela Ludu”, sześć lat później ich liczba wynosiła powyżej 10 000. Jeszcze większym zainteresowaniem cieszył się wydawany od 1913 roku tygodnik „Piast”, pod koniec I wojny światowej gazetę tę prenumerowało około $70000-80000$ osób $^{13}$. Nie można stwierdzić, jaka była rzeczywista liczba odbiorców, do których trafiały treści zamieszczane na łamach chłopskich czasopism. Warto zaznaczyć, że dzięki publicznym odczytom ich krąg znacznie się powiększał.

Powstanie grup reprezentujących interesy chłopów oraz publikacje prasowe i broszury dla ludu przyczyniły się do znacznego rozwoju świadomości społecznej włościan. Chłopi odczuli dzięki tym czynnikom, że są warstwą społeczną zdolną do legalnej walki o swoje prawa i godność ${ }^{14}$. Na wsiach coraz więcej osób próbowało swoich sił w zmaganiach politycznych na szczeblu gminnym, powiatowym, krajowym i ogólnopaństwowym. We Lwowie broniono praw chłopskich w opozycji do grup uprzywilejowanych, w Wiedniu sytuacja ulegała zmianom. Czasami sojusznikami w walce politycznej z innymi nacjami, zasiadającymi w Radzie Państwa, byli przeciwnicy z krajowego sejmu. Chłopi stawali się nie tylko świadomymi swoich praw i obowiązków politykami, ale również działaczami oświatowymi, gospodarczymi i kulturalnymi. Już na najniższych szczeblach zwracano uwagę na znaczenie warstwy włościańskiej oraz potrzebę solidarnej walki o zmiany w kraju. Przykładem może być wypowiedź wójta z Handzlówki, który podczas zwiedzania Krakowa w 1893 roku zapewniał: „My, chłopi, z ochotą przystępujemy do wspólnej z wszystkiemi stanami pracy nad odrodzeniem ojczyzny"

Pomimo wielu zmian, które nastąpiły po uwłaszczeniu i reformach centralnych, nie udało się zlikwidować wszystkich problemów na wsi. Chłopi w dalszym ciągu odczuwali niesprawiedliwość społeczną oraz upośledzenie gospodarcze w stosunku do warstw wyższych. Do najważniejszych różnic zaliczano gorszy dostęp do sądownictwa oraz nierozwiązane kwestie własności gruntów. Antagonizmy na linii chłopstwo-warstwy posiadające trwały do końca omawianego przeze mnie okresu. Przykładem może być tutaj słynna afera z doktorem Jordanem, kiedy to J. Bojko zwrócił mu uwagę:

Wiemy także i to, że choćbyśmy tu z tej strony postawili nie wiem jaki wniosek, to każdy upadnie. Nawet [...] gdybyśmy [...] postawili taki wniosek, żeby można Polskę odbudować, to już tym samym, że wniosek ten wyszedłby z naszej strony, to byście go nie przyjęli1 ${ }^{16}$.

Postulaty chłopskie były niejednokrotnie z góry odrzucane przez pozostałych członków sejmu. Zdarzali się jednak działacze, wywodzący się nawet z ziemiaństwa

\footnotetext{
13 J. Molenda, op. cit., s. 19-20.

14 J. Bojko, Ze wspomnień, s. 225-232.

15 F. Magryś, op. cit., s. 74-75.

16 J. Bojko, Ze wspomnień, s. 230.
} 
i szlachty, którzy swoje polityczne losy związali z organizacjami włościańskimi i często reprezentowali interesy chłopów w sejmach i parlamencie.

Większa świadomość społeczna warstwy chłopskiej oraz walka o samodzielność polityczną spotykały się często z negatywnym odbiorem ze strony duchowieństwa. Walka o wyborców, w której dostojnicy kościelni wspierali szlachtę i ziemian, poparta zakazami czytania prasy ludowej, pozbawianiem funkcji kościelnych księży sprzyjających niezależności chłopów czy ekskomuniką nałożoną na księdza Stojałowskiego, zakończyła się zwycięstwem włościan ${ }^{17}$. Ich ugrupowania funkcjonowały i rozwijały się mimo oskarżeń rzucanych z ambon, niedopuszczania do sakramentów i prób wykluczania chłopów ze społeczności wiernych. Hierarchia kościelna próbowała także powołać do życia własną organizację polityczną, skupiającą w swoich szeregach działaczy wiejskich. Wyrazem tych dążeń była inicjatywa biskupa Leona Wałęgi i utworzenie w 1913 roku Stronnictwa Katolicko-Ludowego ${ }^{18}$.

Emancypacja polityczna chłopów miała wielkie znaczenie dla ich społecznego uświadomienia. Ogromną rolę w tym procesie odegrały także: walka $\mathrm{z}$ analfabetyzmem, upowszechnianie się czytelnictwa prasy i książek, zwiększenie dobrobytu, a także rozwój organizacji społeczno-ekonomicznych, kulturalno-oświatowych i religijnych. Duże znaczenie miały również działania polskich stronnictw politycznych, emigracja i służba wojskowa na frontach I wojny światowej oraz patriotyczne wspomnienia z czasów przedrozbiorowych i powstańczych. Zwalczały one negatywne czynniki hamujące rozwój, takie jak pamięć o pańszczyźnie, mylny obraz „pańskiej” Polski czy mit „dobrego cesarza”.

\section{ROZBUDZENIE TOŻSAMOŚCI NARODOWEJ LUDNOŚCI WIEJSKIEJ GALICJI I JEJ PRZYKŁADY}

Innym elementem mentalności chłopskiej była tożsamość narodowa mieszkańców wsi wraz z jej różnymi przejawami. Kształtowały ją miedzy innymi przywiązanie do symboli narodowych, biało-czerwonych barw, świadomość pochodzenia i znajomość historii narodu. Stanowiła ona także wynik rozwiniętej identyfikacji kulturowej i społecznej z własnym gospodarstwem, warsztatem pracy, rodzinną wsią, środowiskiem przyrodniczym, a także językiem, religią oraz tradycją. W konsekwencji prowadziło to do uświadomienia sobie związków z własnym narodem. Stawało się przejściem od identyfikacji z małą ,prywatną” ojczyzną do ojczyzny ideologicznej ${ }^{19}$.

Posłużę się dwoma rodzajami przykładów. Część z nich odnosi się do odgórnego, wyidealizowanego pojmowania świadomości narodowej, zawartego w programach organizacji reprezentujących ludność chłopską. Pozostałe wiążą się z udziałem włościan w obchodach rocznic i uroczystościach patriotycznych. Masowe uczestnictwo

\footnotetext{
17 J.R. Szaflik, op. cit., s. 194-211, s. 339-344.

18 Ibidem, s. 244-245.

19 H. Brodowska, op. cit., s. 16; J. Molenda, op. cit., s. 34-35.
} 
mieszkańców wsi w tych inicjatywach może być dowodem na rozwój świadomości narodowej w omawianym okresie.

W pierwszej połowie XIX wieku i w początkowej fazie po uwłaszczeniu wydarzenia polityczne, zrywy i powstania narodowe odbywały się najczęściej bez świadomego udziału ludności wiejskiej. Rozwiązanie sprawy chłopskiej stanowiło najczęściej kwestię problemową. Zbyt duże swobody dla włościan wywoływały opór ze strony szlachty, która w tym okresie uważała się za jedynego przedstawiciela narodu. Niewielki udział chłopów w życiu politycznym, gospodarczym i społecznym doprowadził do wytworzenia się stereotypu „chłopa cesarskiego”. Szczególnego znaczenia termin ten nabrał po rabacji galicyjskiej. Wybuch niezadowolenia społecznego, który odczuli przede wszystkim szlachta i ziemianie, miał być powodowany inspiracją zewnętrzną. Nieuświadomiony narodowo, zacofany chłop, upatrujący w monarsze austriackim dobrego władcy i opiekuna w opozycji do złego pana, z którym miał styczność na co dzień, stał się łatwym celem propagandy austriackiej. Taki obraz pokutował jeszcze długo, zarówno w odbiorze zewnętrznym mieszkańców wsi, jak i w ich własnej świadomości ${ }^{20}$. W pamiętnikach chłopskich często pojawiają się określenia cesarza i Austrii jako opiekunów chroniących ludność wiejską. Polskę kojarzono z dominacją dworów i pańszczyzną ${ }^{21}$. Coraz częściej zwracano jednak uwagę, że chłopstwo jest znaczącą siłą, pozbawioną dobrego przywództwa. Umiejętnie pokierowane mogło się przyczynić do realizacji wizji niepodległościowych przy udziale szerokich kręgów społeczeństwa. Jednocześnie w chwilach trudnych powoływano się na Jakuba Szelę, który stanął w obronie praw chłopów przeciwko panom $^{22}$. Łączyło się to jednak $\mathrm{w}$ dalszym ciągu $\mathrm{z}$ niską świadomością narodową ludności włościańskiej. Działacze prowadzący swoją misję wśród chłopów, między innymi ksiądz Stojałowski i J. Bojko, starali się promować zmianę nastawienia do wizji niepodległego państwa polskiego, krytykując przywódcę rabacji i jego legendę 23 . Utrzymywanie się stereotypu „chłopa cesarskiego” zanikało powoli wraz z rozwojem świadomości społecznej i narodowej. Dużą rolę w tym procesie odgrywali ludzie propagujący w swoich społecznościach sprawę narodową poprzez czytelnictwo polskich książek oraz organizację pielgrzymek patriotycznych do miejsc narodowej pamięci.

Ogromną rolę w uświadomieniu chłopów odegrali pionierzy i działacze ruchu ludowego. Prowadzili oni akcje mające na celu aktywizację polityczną i społeczną ludności włościańskiej. Pierwszymi działaczami pracującymi wśród ludu byli emisariusze organizacji demokratycznych oraz przedstawiciele warstw wyższych, którzy dostrzegali potrzebę uświadomienia narodowego chłopów. Do najważniejszych z nich należeli ksiądz Stanisław Stojałowski (1845-1911) oraz Maria i Bolesław Wysłouchowie. Pierwszy z nich, pochodzący z rodziny szlacheckiej, od lat 70. XIX wieku prowadził działalność na terenie Galicji. Był inicjatorem

20 T. Kargol, Między rabacją a niepodległościa. O świadomości narodowej chłopów w Galicji w XIX stuleciu, „Arcana” 2015, nr 121, s. 111-112.

${ }_{21}$ W. Witos, op. cit., s. 104, 106-108.

22 Ibidem, s. 141.

23 F. Ziejka, op. cit., s. 255-257. 
powstania organizacji oświatowych i kulturalnych oraz ożywienia działalności gospodarczej chłopów, propagował także uświadomienie narodowe poprzez pielgrzymki patriotyczne i udział w obchodach uroczystości narodowych. Od 1875 roku wydawał też czasopisma dla ludu - „Wieniec” i „Pszczółkę”. Za swoją działalność był szykanowany przez władze świeckie i duchowne. W 1889 roku został suspendowany, a w 1896 roku - wyklęty. Jego oddziaływanie na środowiska wiejskie okazało się bardzo duże. W wiecach organizowanych przez Stojałowskiego uczestniczyły tłumy. Dorobek księdza, który szerzył na wsi postawy patriotyczne i obywatelskie oraz dbał o rozwój świadomości narodowej, stał się fundamentem dla wielu późniejszych działaczy stronnictw i organizacji chłopskich ${ }^{24}$.

Do pionierów uświadomienia narodowego chłopów zaliczali się także Bolesław Wysłouch (1855-1937) i jego żona Maria (1858-1905). Miejscem ich walki o prawa polityczne i narodowe chłopów stały się główne czasopisma, których byli inicjatorami - „Przegląd Społeczny” i „Przyjaciel Ludu”. Bolesław Wysłouch przyczynił się do założenia Stronnictwa Ludowego, a później na stałe związał się z politycznym ruchem chłopskim. Maria Wysłouchowa dała się poznać jako organizatorka kół oświaty ludowej, propagatorka postaw obywatelskich i narodowych, inicjatorka życia gospodarczego kobiet wiejskich. W 1890 roku wraz z mężem założyła Towarzystwo Przyjaciół Oświaty, które zajmowało się organizowaniem czytelni wiejskich, wykładów i pogadanek oraz oświatą. Z ich inicjatywy na wsiach powstało wiele bibliotek i czytelni. Maria Wysłouchowa wydawała także czasopisma dla kobiet: „Przodownica” $\mathrm{i}$ „Zorza”. W pamiętnikach chłopskich często zwraca się uwagę na rolę, jaką odegrała podczas obchodów 100-lecia bitwy racławickiej, kiedy to we Lwowie współorganizowała wielką uroczystość o charakterze patriotycznym ${ }^{25}$.

Działalność pionierów ruchu ludowego poprzedzała powstanie zorganizowanych partii i stronnictw, dążących do promocji świadomości narodowej wśród chłopów w Galicji. Analiza poszczególnych koncepcji narodowości w programach politycznych ugrupowań włościańskich jest doskonałym odzwierciedleniem propagowanych wśród ludności wiejskiej postaw. Pierwsze odwołanie do kwestii polskości znajdujemy w Szkicach programowych z 1886 roku, ogłoszonych przez Bolesława Wysłoucha na łamach „Przeglądu Społecznego". Zwracał on uwagę na to, że w dotychczasowych dążeniach stronnictw politycznych nadrzędnym celem była niepodległość Polski. W dalszej części kładł nacisk na liczebność „12-milionowej grupy etnograficznej polskiej, która jest rękojmią narodowego bytu i podstawą realną praw narodowych, sankcją etyczno-społeczną". Głównym celem ludu miało być dążenie do niepodległości w ramach „wszystkich części etnograficznej Polski, zjednoczonych w jedną całość"26. Program ogłoszony przez Wysłoucha pokazuje, jaką wizję tożsamości narodowej propagowały elity pracujące wśród ludności wiejskiej.

Późniejszy o kilka lat statut pierwszej partii włościańskiej, powstałego w Nowym Sączu w lipcu 1893 roku Związku Stronnictwa Chłopskiego, również odwołuje

24 F. Kącki, Ks. Stanisław Stojałowski i jego działalność spoteczno-polityczna (1845-1890), Lwów 1937; J.R. Szaflik, op. cit., s. 110-132.

${ }_{25}$ Historia chtopów polskich..., s. 476-477; J. Bojko, Ze wspomnień, s. 266-274.

26 Programy stronnictw ludowych..., s. 27-48. 
się do kwestii narodowej. Przez aktywność zmierzającą do „podniesienia swojego stanu” chłopi dążą „do podniesienia narodu”. Dostrzegają oni też istnienie „oprócz spraw włościańskich, spraw wspólnych, spraw całego narodu, kraju i państwa"27. $\mathrm{O}$ ile program ogłoszony przez Wysłoucha ukazywał kwestię narodową w ujęciu intelektualistów pracujących wśród ludności wiejskiej, o tyle w przypadku statutu ZSCh możemy mówić o rozumieniu pojęcia narodu przez włościan. Przywódcy tego ruchu w większości wywodzili się z ludności wiejskiej spod Nowego Sącza i pełnili w swoich gminach funkcje przedstawicielskie.

Szerzenie postaw obywatelskich i narodowych stanowiło także główny cel powstałego w 1895 roku w Rzeszowie Stronnictwa Ludowego (od 1903 r. Polskiego Stronnictwa Ludowego). Już w odezwie programowej z 1895 roku Galicja została ukazana jako dzielnica „naszej Polski”, a włościaństwo jako „żywioł narodowy”, który okazuje swoje przywiązanie do polskości przez udział w uroczystościach patriotycznych. Poprawa jego doli to cel leżący w interesie „całego kraju i narodu”"28. W programie z 1903 roku kwestie narodowe uznano za nadrzędne. Rozwój polityczny, ekonomiczny i cywilizacyjny uznano za czynnik najważniejszy, prowadzący do polepszenia losu narodu. Innym postulatem było dążenie do usamodzielnienia się Galicji, gdyż „naród polski miał być gospodarzem ziemi, na której żyje”29. Pozostałe odłamy politycznego ruchu chłopskiego również ukazywały ogromne znaczenie kwestii narodowej. Za przykład może posłużyć program Stronnictwa Chrześcijańsko-Ludowego z 1896 roku, w którym narodowość traktowano ,jako dar przyrodzony”. Dążono także do niezależności uznanej za „dopełnienie i koronę narodowego bytu" $"$.

Przed wybuchem I wojny światowej, a także w czasie jej trwania wielokrotnie powracano do spraw uświadomienia narodowego ludności chłopskiej oraz autonomii dla Galicji, która ostatecznie miałaby prowadzić do niepodległości. Na łamach „Przyjaciela Ludu” i „Piasta” pojawiały się publikacje oraz artykuły nawiązujące do narodu polskiego oraz ukazujące przykłady postaw patriotycznych i obywatelskich. Po rozłamie w ruchu ludowym z 1913 roku i powstaniu PSL „Piast” oraz PSL „Lewicy” w artykułach programowych stawiano sobie za cel rozwój świadomości narodowej w obliczu przemian, jakie niosła ze sobą wojna ${ }^{31}$.

Analizując programy polityczne partii chłopskich z przełomu XIX i XX wieku, zapoznajemy się z idealistyczną wizją tożsamości narodowej. W takiej formie była ona propagowana przez pionierów, działaczy i przywódców organizacji chłopskich. Przykłady recepcji postaw narodowych możemy ukazać także poprzez oddolne zachowania ludności włościańskiej. Najważniejszym z nich było uczestnictwo w obchodach rocznic narodowych i świąt patriotycznych.

27 Ibidem, s. 49-53.

28 Ibidem, s. 53-62.

29 Ibidem, s. 62-68.

30 Ibidem.

31 Bijmy się jako jeden naród, „Piast” 1915, nr 38; O przyszłość Polski, „Piast” 1916, nr 45; Proklamowanie niepodległości przez naród, „Piast” 1917, nr 22; Polska zmartwychwstała, „Piast” 1918, nr 41. 
W drugiej połowie XIX stulecia w wielu pamiętnikach chłopskich pojawiają się opisy obchodów wielkich rocznic narodowych z udziałem ludności włościańskiej. W samej Galicji miały się odbyć 472 imprezy nawiązujące do tradycji polskości. Najwięcej z nich zorganizowano z okazji rocznic związanych z legendą kościuszkowską i Racławicami - aż 132. Na kolejnych miejscach znalazły się obchody rocznic: powstania 1863 roku - 78, bitwy pod Grunwaldem - 74, Konstytucji 3 maja - 49, powstania listopadowego - 30, oraz uroczystości na cześć wieszczów narodowych i zasłużonych ludzi kultury (Marii Konopnickiej, Adama Mickiewicza, Juliusza Słowackiego, Stanisława Wyspiańskiego i in.) - około $50^{32}$.

W świadomości chłopskiej funkcjonowały mity związane z polską tradycją historyczną. Była to legenda kościuszkowska wraz z jej elementami chłopskimi (udział kosynierów, postać Bartosza Głowackiego) przeciwstawiona negatywnej legendzie Jakuba Szeli oraz rabacji galicyjskiej ${ }^{33}$. We wspomnieniach Witosa znajdujemy opis, jak zmieniała się wizja Naczelnika w sukmanie w oczach chłopów ${ }^{34}$. Z buntownika przeciwko władzy królów i cara, pochodzącej od Boga, urastał on do symbolu walki o poprawę chłopskiej doli. Szczególnego znaczenia nabrała wizja dziejów ukazana w Panoramie Racławickiej przez Jana Stykę i Wojciecha Kossaka. Przywoływano obraz Kościuszki ubranego w strój chłopski, postać Bartosza Głowackiego oraz rolę, jaką odegrali kosynierzy w bitwie racławickiej. Przywiązanie do jej legendy zostało zamanifestowane podczas setnej rocznicy insurekcji, połączonej z wystawą krajową we Lwowie w 1894 roku, kiedy to została odsłonięta Panorama Racławicka. Trwała także pamięć o Bartoszu Głowackim, którego pomnik odsłonięto w 1904 roku w Tarnobrzegu ${ }^{35}$. Najdobitniejszym utrwaleniem legendy racławickiej było Wesele Stanisława Wyspiańskiego. Dramaturg ukazał chłopa jako obrońcę narodu. W utworze następuje totalne odrzucenie wizji reprezentowanej przez Jakuba Szelę i rabację galicyjską. Do Kościuszki nawiązywano także na wiecach politycznych podczas I wojny światowej. Uwidoczniło się to w rezolucji Tetmajera z 1917 roku, w której hasła „Całość, wolność, niepodległość” były zaczerpnięte ze sztandarów powstańców $^{36}$. Legenda kościuszkowska, odgórnie zaimplementowana do kultury ludowej, wpłynęła na rozwój świadomości narodowej chłopów oraz ich masowy udział w obchodach uroczystości patriotycznych.

Wczytując się w pamiętniki chłopów, poznajemy przebieg tych uroczystości, ich charakter, doniosłość oraz rolę, jaką odgrywały w rozbudzaniu tożsamości narodowej ludności włościańskiej. Chronologicznie, w omawianym okresie do największych z nich można zaliczyć 200. rocznicę bitwy pod Wiedniem. Wówczas wielu chłopów pierwszy raz zetknęło się z pamiątkami narodowej historii ${ }^{37}$. Kolejnym ważnym wydarzeniem był pogrzeb Adama Mickiewicza, który odbył się w Krakowie w 1890 roku. Z prasy i ze wspomnień wiemy, że na tę uroczystość przybyło kilka

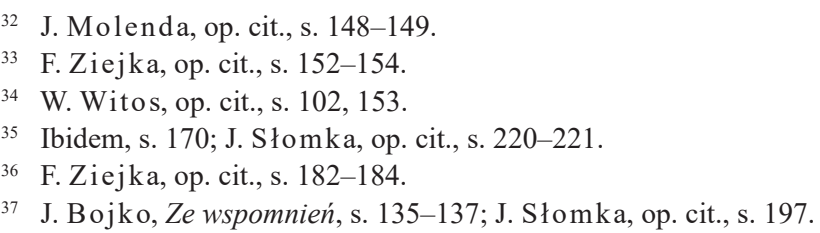


tysięcy włościan ${ }^{38}$. Jednym z ważniejszych wydarzeń była setna rocznica insurekcji, połączona z wystawą krajową we Lwowie w 1894 roku. Uczestniczyło w niej 3000 chłopów ubranych w sukmany z liśćmi bluszczu w klapach. Jak wspomina J. Bojko:

Precz z żalem i smutkiem, bo oto jesteśmy na racławickich polach! Ach mój Boże, dlaczego każdego Polaka taki zapał unosi przy wymówieniu tego magnetycznego słówka? Czy powtórzą się jeszcze kiedy Racławice z takim, a właściwie jeszcze świetniejszym, zupełniejszym zwycięstwem? [...] Człek został przeniesiony w inny świat i zobaczył niby na szczerej jawie, co mogą złączone siły narodu dokazać... ${ }^{39}$

Spośród wielu wydarzeń o charakterze narodowym, w których brała udział ludność włościańska, można jeszcze wspomnieć obchody związane z 40-leciem wybuchu powstania styczniowego w 1903 roku $^{40}$.

Najsłynniejszymi uroczystościami, które znalazły swój oddźwięk w pamiętnikach chłopskich, prasie i wielu innych źródłach z epoki, były obchody 500-lecia bitwy grunwaldzkiej w 1910 roku. Przypadły one na czas, w którym polityczny ruch chłopski był silnie rozwinięty i prowadził szeroko zakrojoną działalność, mającą na celu uświadomienie narodowe ludności wiejskiej. Na największym wiecu w Krakowie, będącym manifestacją nastrojów patriotycznych, zebrało się wtedy wiele tysięcy ludzi z ziem trzech zaborów. Areną promocji postaw obywatelskich i narodowych stały się wtedy miejsca związane z historią i tradycją, takie jak: Wawel, kopiec Kościuszki czy plac, na którym odsłonięto Pomnik Grunwaldzki. Rocznicę zwycięstwa polskiego oręża świętowano także w wielu miasteczkach i wsiach w całym kraju ${ }^{41}$. Jak wspomina Witos: „Gdzie spojrzeć, widziało się wszędzie barwne stroje ludowe i narodowe, którymi zostały zasiane wszystkie ulice i place Krakowa" ${ }^{\prime 2}$.

Jedną z ostatnich rocznic obchodzonych przed odzyskaniem niepodległości była setna rocznica śmierci Tadeusza Kościuszki w 1917 roku. Działacze chłopscy zebrani w Krakowie i Racławicach przypominali wtedy o roli, jaką odegrał Naczelnik w sukmanie. Z kopca Kościuszki do zgromadzonego ludu przemawiał Jakub Bojko. W miejscu bitwy racławickiej zebrało się wtedy wiele tysięcy chłopów z całej Galicji i Królestwa Polskiego ${ }^{43}$.

Ciekawym przykładem wytworzenia się własnej tradycji chłopskiej na podstawie mitu kościuszkowskiego było Święto Ludowe. Ustanowiono je na Radzie Naczelnej PSL 30 maja 1903 roku, aby 4 kwietnia roku następnego uczcić 110. rocznicę bitwy pod Racławicami. Organizowano obchody przez trzy lata, a następnie zaprzestano ich aż do 1928 roku, kiedy to przywrócono je w niepodległej Polsce. Stały się one symbolem łączącym wszystkie pokolenia chłopów dzięki legendzie Naczelnika w sukmanie i bitwy racławickiej ${ }^{44}$.

38 Uroczystości pogrzebowe nieśmiertelnej pamięci wieszcza narodu naszego Adama Mickiewicza w Krakowie, „Pszczółka Ilustrowana” 1890, nr 13; J. Słomka, op. cit., s. 197.

39 J. Bojko, Ze wspomnień, s. 210-215.

40 H. Brodowska, op. cit., s. 122-123.

${ }_{41}$ J. Hampel, op. cit., s. 44-45; J. Molenda, op. cit., s. 206-207.

42 W. Witos, op. cit., s. 237-238.

43 F. Ziejka, op. cit., s. 182-184.

44 J. Gmitruk, Święto ludowe w panoramie dziejów ruchu ludowego, Warszawa 2003. 
U progu niepodległości Polski coraz częściej ujawniały się postawy świadczące o dojrzałości tożsamości narodowej i obywatelskiej wśród chłopów. Politycy związani z ruchem ludowym w okresie I wojny światowej podjęli działania mające na celu ochronę ludności wiejskiej, przy jednoczesnym propagowaniu postaw narodowych. W końcowym etapie wojny skupiano się na ukazywaniu jedności pomiędzy poszczególnymi częściami ziem polskich oraz propagowaniu wizji niepodległej Polski. Ewoluowała ona od sprawy wyodrębnienia Galicji do pełnej niezależności na ziemiach zamieszkanych przez Polaków. Oddolnym wyrazem identyfikacji z narodem polskim były listy czytelników wysyłane do redakcji „Piasta”. Ich liczba w okresie wojny sięgnęła 2874 . Około $600 \mathrm{z}$ nich dotyczyło rocznic i uroczystości narodowych. W innych poruszano kwestie szkolnictwa i oświaty oraz tematykę narodową i niepodległościową̨ ${ }^{45}$.

Znaczącym przejawem utożsamiania się ludności chłopskiej z nastrojami niepodległościowymi i narodowymi był masowy udział w wiecach poparcia i protestach wobec niekorzystnych rozstrzygnięć dotyczących kwestii polskiej. Szczególnie ujawniło się to po pokoju brzeskim, na przełomie lutego i marca 1918 roku. W wielu miastach i wsiach Galicji doszło wtedy do wystąpień przeciwko przyłączeniu Chełmszczyzny do mającej powstać Ukrainy ${ }^{46}$. Masowe wiece zorganizowano również w maju 1917 roku, kiedy to poseł Włodzimierz Tetmajer ogłosił rezolucję zawierającą postulat niepodległości Polski złożonej z ziem trzech zaborów ${ }^{47}$. Pomimo licznych dowodów oddania sprawie narodowej $\mathrm{w}$ dalszym ciągu dostrzegano braki oraz nierozwiązane problemy. Wiązały się one z niską świadomością chłopów oraz nierównościami społecznymi w obliczu powstającego niepodległego państwa polskiego. Warto tutaj przytoczyć wypowiedzi przedstawicieli chłopstwa z powiatu brzeskiego, którzy swoje obawy kierowali do przyszłego premiera Wincentego Witosa:

[...] Prezesie, ja jestem dobrym Polakiem, pragnę całą duszą, ażeby Polska powstała, cieszę się na ten dzień, w którym się to stanie, nie żałuję naszej krwi ani też ofiar, ale moją radość wciąż mąci obawa, że my dostaniemy własne państwo, ale niewoli się nie pozbędziemy wcale. [...] Chłopi są przekonani, że ta niewola będzie jeszcze większa, aniżeli jest teraz, bo chłopi nasi są jeszcze za głupi, a panów i urzędników jest za dużo. Byłoby lepiej, żeby to jeszcze później nastąpiło, gdy chłopi więcej zmądrzeją ${ }^{48}$.

Nawet w kręgach uświadomionych chłopów pojawiały się jeszcze wtedy odosobnione przypadki kwestionowania potrzeby zmiany stosunków społecznych. Świadczy o tym stwierdzenie wieloletniego posła i wójta spod Krakowa - Franciszka Ptaka: „Co ty, Wicek, myślisz, czy jak ta Polska powstanie, to będzie chłopom choć odrobinę lepiej, bo ja myślę, że przyjdą szlacheckie rządy i nowa pańszczyzna" "49. Były to jednak już głosy chłopów, którzy w obliczu nowej sytuacji społeczno-politycznej zwracali uwagę na potrzebę dalszej walki o prawa ludności włościańskiej i jeszcze większe uświadomienie ludu.

\footnotetext{
45 J. Molenda, op. cit., s. 15-16.

46 J.Z. Pająk, op. cit., s. 201-227.

47 Ibidem, s. 193-194; W. Witos, op. cit., 386-391.

48 W. Witos, op. cit., s. 367-368.

49 Ibidem, s. 391-392.
} 


\section{PODSUMOWANIE}

Niniejsza próba ukazania ewolucji tożsamości chłopów galicyjskich może prowadzić do konkluzji, że w drugiej połowie XIX i na początku XX wieku doszło do ogromnych zmian w mentalności ludności wiejskiej. Dzięki tradycji historycznej, a także przynależności językowej i kulturowej doszło do ukształtowania się tożsamości społecznej i politycznej oraz świadomości narodowej chłopów. Był to długotrwały proces, którego przyspieszenie nastąpiło dzięki przemianom gospodarczo-społecznym na terenie Galicji. Reformy uwłaszczeniowe, a także większy udział społeczności chłopskiej w życiu politycznym, najpierw gminnym, a następnie na wyższych szczeblach władzy, zdynamizowały przemiany w kierunku społeczeństwa obywatelskiego, chłopa świadomego swojego miejsca w strukturze narodu, umiejącego bronić swoich praw i przywilejów.

Dużą rolę odegrały narodowe mity dotyczące insurekcji kościuszkowskiej, postaci Bartosza Głowackiego, udziału kosynierów w bitwie racławickiej. Zwalczały one czarną legendę rabacji galicyjskiej i stereotyp zacofanego chłopa cesarskiego. Dzięki tradycji kościuszkowskiej udało się częściowo zlikwidować negatywny obraz włościanina w świadomości warstw wyższych oraz rozbudzić patriotyzm wśród mieszkańców wsi.

W drugiej połowie XIX wieku na scenę polityczną weszły jednostki i ugrupowania reprezentujące dążenia społeczne i polityczne chłopów. Ich pojawienie się znacząco wpłynęło na zmiany w wiejskiej mentalności. Ogromną rolę w kształtowaniu się postaw obywatelskich i narodowych odegrali także działacze prowadzący swą misję pośród ludu - emisariusze demokratyczni, księża, społecznicy, nauczyciele i politycy. Rozwój ich działalności, połączony z powstawaniem prasy i publicystyki ludowej, przyczynił się także do zmian w świadomości włościan. Duże znaczenie miała także oświata. Dzięki powstawaniu szkół ludowych najniższego szczebla udawało się często kreować świadomość społeczną i narodową.

Przykładem ewolucji postaw patriotycznych i obywatelskich był także udział chłopów w uroczystościach narodowych oraz protestach przeciwko działaniom władz austriackich. Można powiedzieć, że w przeddzień odzyskania niepodległości duża część społeczności wiejskiej była dojrzała społecznie i narodowo. Mieszkańcy Galicji Zachodniej czuli się Polakami, którym nieobce były losy współbraci z innych zaborów. Już po odzyskaniu niepodległości miało to zaowocować licznym udziałem chłopów w wojnie polsko-bolszewickiej oraz piastowaniem wielu ważnych funkcji społecznych i politycznych w państwie przez przedstawicieli środowisk wiejskich. 


\section{BIBLIOGRAFIA}

\section{I. Źródła}

\section{Wydawnictwa źródłowe}

Programy stronnictw ludowych. Zbiór dokumentów, red. S. Lato, W. Stankiewicz, Warszawa 1969.

\section{Wspomnienia}

Bojko J., Dwie dusze, Warszawa 1949.

Bojko J., Ze wspomnień, Warszawa 1959.

Magryś F., Żywot chłopa działacza, Handzlówka 2004.

Słomka J., Pamiętniki włościanina od pańszczyzny do dni dzisiejszych, Kraków 1929.

Witos W., Moje wspomnienia, cz. 1, Warszawa 1998.

\section{Prasa}

„Piast” (Kraków) 1915-1918.

„Pszczółka Ilustrowana” (Gródek Jagielloński) 1890.

\section{Opracowania}

Brodowska H., Chłopi o sobie i Polsce. Rozwój świadomości narodowej, Warszawa 1984.

Gmitruk J., Święto ludowe w panoramie dziejów ruchu ludowego, Warszawa 2003.

Gmitruk J., Mazurek J., Tradycja kościuszkowska w ruchu ludowym, Warszawa 2004.

Grodziski S., Sejm Krajowy Galicyjski 1861-1914, Warszawa 1993.

Hampel J., Chłopów polskich drogi do demokracji. Studia i szkice, Kraków 2008.

Historia chłopów polskich, t. 2: Okres zaborów, red. S. Inglot, Warszawa 1972.

Insurekcja kościuszkowska $w$ dziejach i tradycji, red. J. Gmitruk, A. Stawarz, Warszawa 2004.

Kargol T., Między rabacją a niepodległością. O świadomości narodowej chtopów w Galicji w XIX stuleciu, „Arcana” 2015, nr 121, s. 99-112.

Kącki F., Ks. Stanisław Stojałowski i jego działalność społeczno-polityczna (1845-1890), Lwów 1937.

Molenda J., Chłopi, naród, niepodlegtość. Kształtowanie się postaw narodowych i obywatelskich chłopów w Galicji i Królestwie Polskim w przededniu odrodzenia Polski, Warszawa 1999.

Pająk J.Z., Od autonomii do niepodległości. Kształtowanie się postaw politycznych i narodowych społeczeństwa Galicji w warunkach Wielkiej Wojny 1914-1918, Kielce 2012.

Stauter-Halsted K., The Nation in the Village. The Genesis of Peasant National Identity in Austrian Poland, 1848-1914, New York-London 2001.

Szaflik J.R., O rzad chtopskich dusz, Warszawa 1976.

Ziejka F., Złota legenda chłopów polskich, Warszawa 1984. 